\title{
Numerical Analysis of the Impact of Thermal Spray Insulation Solutions on Floor Loading
}

\author{
Anna Szymczak-Graczyk (D)
}

Institute of Construction and Geoengineering, Faculty of Environmental Engineering and Spatial Management, Piatkowska Street 94, Poznan University of Life Sciences, 60-649 Poznan, Poland;

anna.szymczak-graczyk@up.poznan.pl; Tel.: +48-602-516-345

Received: 12 January 2020; Accepted: 30 January 2020; Published: 4 February 2020

\begin{abstract}
The paper presents the effect of considering the substrate under the floor-insulation in the form of closed-cell polyurethane spray foam, which is used for insulating surfaces particularly exposed to mechanical impact. The layer of thermal insulation was made by spraying, which prevents the occurrence of thermal bridges due to tight filling of the insulated space. It seems extremely important to adopt the appropriate material characteristics of an insulating layer. The basic thermophysical properties of polyurethane foam justifying its choice as an insulation material were the values of its thermal conductivity coefficient $(0.022 \mathrm{~W} /(\mathrm{mK}))$ and density $\left(36 \mathrm{~kg} / \mathrm{m}^{3}\right)$. However, what was the most important for the calculations provided in the work was to determine the stiffness of the foam subgrade so as to assess its impact on the floor load capacity. The paper includes calculations for a floor slab characterized by a static diagram, with all edges free (unfixed), loaded in strips circumferentially. The reinforced concrete slab was $6 \times 6 \mathrm{~m}$ long, $0.25 \mathrm{~m}$ thick, and made of C20/25 concrete resting on an elastic substrate. Calculations were made for two variants taking into consideration two values of subgrade stiffness. The first variant concerned the subgrade stiffness for sprayed polyurethane foam insulation. On the basis of laboratory tests in situ made according to the standard procedure, its average value was assumed as $\mathrm{K}=32,000 \mathrm{kN} / \mathrm{m}^{3}$. The second, comparative, computational variant included the subgrade stiffness equal to $K=50,000 \mathrm{kN} / \mathrm{m}^{3}$. A variation approach to the finite difference method was used for static calculations, adopting the condition for the minimum energy of elastic deformation while undergoing bending that was accumulated in the slab resting on a Winkler elastic substrate. Static calculations resulted in obtaining the values of deflections at each point of the discretization grid adopted for the slab. The obtained results have proved the necessity of calculating the floor as a layer element. For the reference substrate with the subgrade stiffness $\mathrm{K}=50,000 \mathrm{kN} / \mathrm{m}^{3}$ that was adopted in the work, the value of the bending moment was $17 \%$ lower than when taking into account that there was thermal insulation under the floor slab, causing an increase in the deflection of the slab and an increase in its bending moment. If a design does not include the actual subgrade stiffness of the layer under the floor slab, it results in an understatement of the values of the bending moments on the basis of which the slab reinforcement is designed. Adherence of insufficient concrete slab reinforcement may cause subsequent damage to floor slabs.
\end{abstract}

Keywords: floor slabs; spray insulation; closed-cell polyurethane foam; Winkler elastic substrate; subgrade stiffness; finite difference method

\section{Introduction}

The structure of a building consists of individual structural elements whose main task is to transfer loads originating from the function and purpose of the object. Sometimes these loads can result in an interesting dynamical phenomenon, such as nonlinear energy transfer [1,2] or mode location. One of the basic structural elements found in each building are floor slabs. They must be designed accordingly 
as to ensure trouble-free use of floors, which are made of structural and surface layers (finishing). The improper design of floor slabs may result in subsidence, scratches, or cracks [3,4]. Damage visible in the top layer of a floor also contributes to local chipping or peeling as well as the detachment of resin coatings and modification of surface evenness $[5,6]$. The correct design of floors requires proper recognition of the substrate beneath and treating it as a layered system. The most commonly applied calculation scheme for a floor slab includes a plate on a Winkler elastic substrate. The Winkler model specifies a substrate with one single parameter, assuming that the working load is equal to the product of plate deflection and subgrade stiffness.

Any point of the surface of the substrate dislocates independently from one another. This is because at each point, the medium of the substrate contains a flexible independent spring with equal stiffness and an infinitely close arrangement $[7,8]$. In a different way, a Winkler substrate has been defined as a system of densely spaced rods having a specific flexural stiffness [9]. A more accurate model is an elastic layer presented in an approximate manner. The coefficients included in calculations are dependent on the material constants specific to this layer [10]. Another option is to assume that the substrate is liquid whose specific gravity is later included in calculations. Then, the buoyancy is exerted by the weight of the plate that lies on a given floating substrate [11]. Figure 1 schematically presents the Winkler elastic substrate, while Formula (1) indicates the above-described correlation [11].

$$
\mathrm{p}=K_{z} \cdot w
$$

where:

$\mathrm{p}-$ load $\left[\mathrm{kN} / \mathrm{m}^{2}\right]$

$w$-deflection $[\mathrm{m}]$

$K_{z}$ - subgrade stiffness $\left[\mathrm{kN} / \mathrm{m}^{3}\right]$

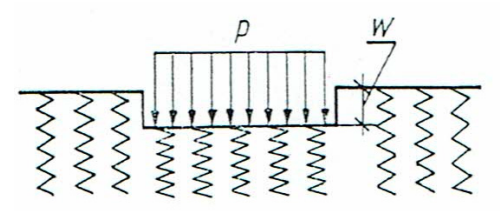

Figure 1. Winkler substrate model [11].

Two-parameter substrate models such as Vlasov, Pasternak or Gorbunov-Posadov systems of equations are much less frequently used, since it is more difficult to make calculations using them [12-15]. Floors in heated buildings are thermally insulated to minimize heat loss. The literature provides insufficient information regarding the effect of a thermal insulation layer on the total load capacity of the floor slab above it. There are many thermal insulation materials, i.e., polystyrene, mineral wool, glass wool, resole foam, foam glass, or cellulose insulation material. Recently, the popularity of polyurethane foam as a thermal insulator has been noticeably increasing [16-18]. The production of polyurethanes constitutes approximately $7 \%$ of the total plastics production in Europe $[19,20]$. Certainly, polyurethane can be used as floor insulation, e.g., sandwich panels with a polyurethane foam core in aluminum cladding. The calculations that include the cooperation of a reinforced concrete slab and sandwich panels demonstrate an increase in the value of the subgrade stiffness reaction in combination with a decrease in the value of bending moments [7]. However, floor insulation is very rarely made in the form of spraying, as insulation boards are much easier to lay.

The work contributes to further considerations on floor design as sandwich elements, with different stiffness moduli of individual layers. In the literature available to engineers, there are no algorithms for designing such floors. The issue is particularly important from the point of view of contractors and investors. Floors in building structures are a cost-generating element; hence, their correct design is critical. The paper includes an insulation layer made of spray-applied polyurethane 
foam. Although such a solution is rarely used in floor making, its undoubted advantage, apart from thermal insulation properties, is the tightness of the layer.

\section{Materials and Methods}

\subsection{Laboratory Tests}

The present study uses the results of in situ tests carried out in order to determine the value of the stiffness subgrade of an insulation layer made of closed-cell polyurethane spray foam. The subject of the tests was polyurethane foam used for insulating surfaces particularly exposed to mechanical impact with the following parameters: thermal conductivity coefficient $\lambda=0.022 \mathrm{~W} /(\mathrm{mK})$, density in the range of $34-37 \mathrm{~kg} / \mathrm{m}^{2}$, closed cell content approximately $95 \%$, water absorption $\leq 0.20 \mathrm{~kg} / \mathrm{m}^{2}$. The tested material was taken from the construction site; the sheets were $60 \times 120 \mathrm{~cm}$, from which $20 \times 20 \mathrm{~cm}$ test samples were made. The temperature in the laboratory where the samples were stored was $24^{\circ}$ and they were stored for $6 \mathrm{~h}$ prior to testing. The tests cited in the paper was carried out with the use of 40 samples, $7 \mathrm{~cm}$ to $16 \mathrm{~cm}$ thick, according to [21,22].

Figure 2 shows the measuring stand for conducting compressive strength tests of polyurethane foam samples and configuration of the universal testing machine prepared to perform the test (b). The force reading with an accuracy of $0.5 \mathrm{kN}$ was carried out when the tested sample obtained $10 \%$ relative strain [21].

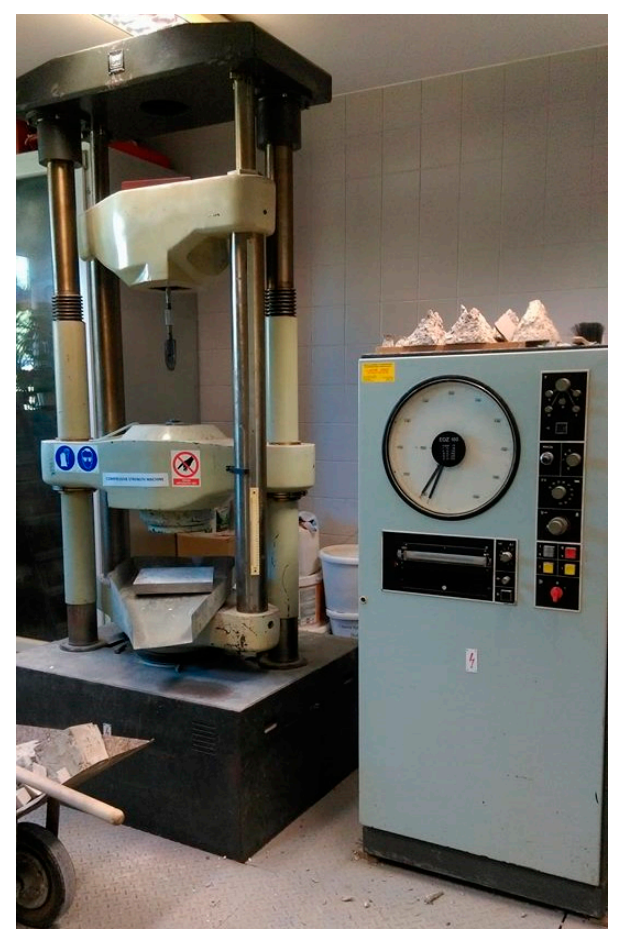

(a)

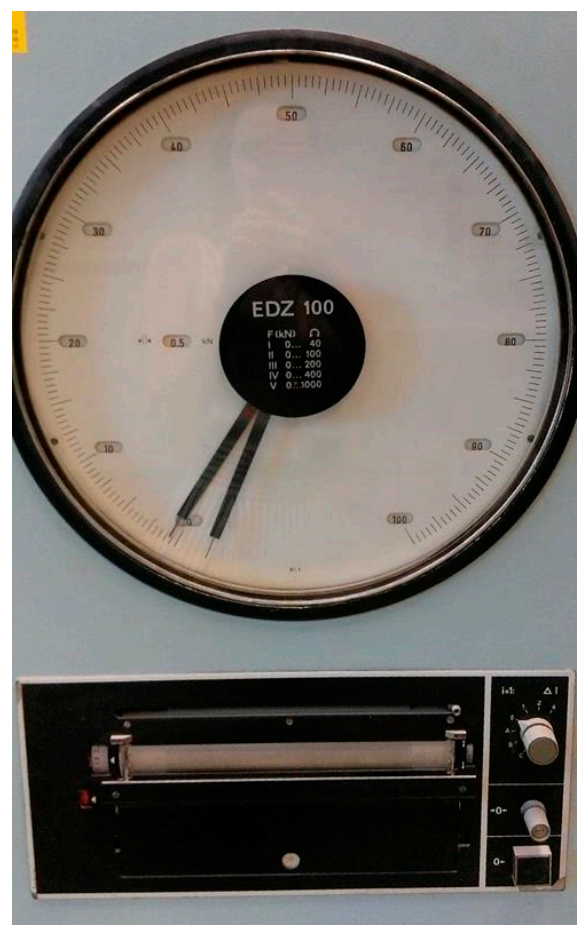

(b)

Figure 2. Measuring stand for compressive strength tests (a) and measuring disc of the universal testing machine with configuration of the clock (b).

Figure 3 shows a sample made of polyurethane foam during the test (a) and the straight edge with a measuring accuracy of $1 \mathrm{~mm}$ used for measuring the deflection of the samples (b), while Figure $3 \mathrm{c}$ illustrates the universal testing machine with a visible straight edge prior to testing.

We determined the average compressive stresses at $10 \%$ relative strain for a given thickness [21]. Formula (1) provided the basis to determine the subgrade stiffness for a given thickness, which was followed by determination of the average subgrade stiffness calculated from 40 tests. To carry out the 
tests, 40 samples were used in the following configuration: for $16 \mathrm{~mm}$ thickness, 2 samples; $14.5 \mathrm{~mm}$, 1 sample; $14 \mathrm{~mm}, 3$ samples; $13.5 \mathrm{~mm}, 1$ sample; $13 \mathrm{~mm}, 5$ samples; $12.5 \mathrm{~mm}, 1$ sample; $12 \mathrm{~mm}$, 2 samples; $10.5 \mathrm{~mm}, 2$ samples; $9.5 \mathrm{~mm}, 3$ samples; $9 \mathrm{~mm}, 3$ samples; $8.5 \mathrm{~mm}, 3$ samples; $8 \mathrm{~mm}$, 10 samples; $7.5 \mathrm{~mm}, 1$ sample; and $7 \mathrm{~mm}, 3$ samples. The average compressive stress at $10 \%$ relative strain was determined for each of the thicknesses listed above, as provided in Table 1 . Table 1 sets out the average compressive stress at $10 \%$ relative strain for a given thickness [23] and the determined average subgrade stiffness reaction for each sample thickness, followed by the average subgrade stiffness reaction obtained from all performed tests.

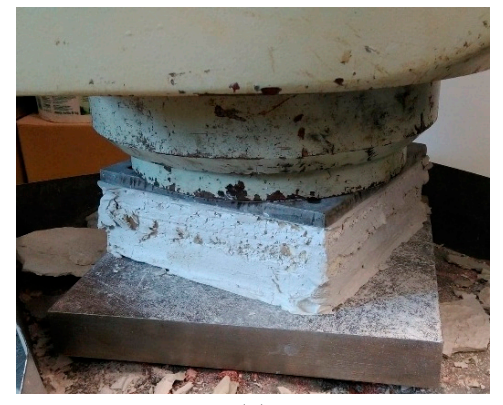

(a)

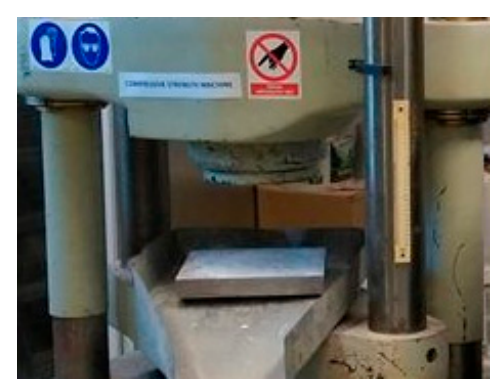

(c)

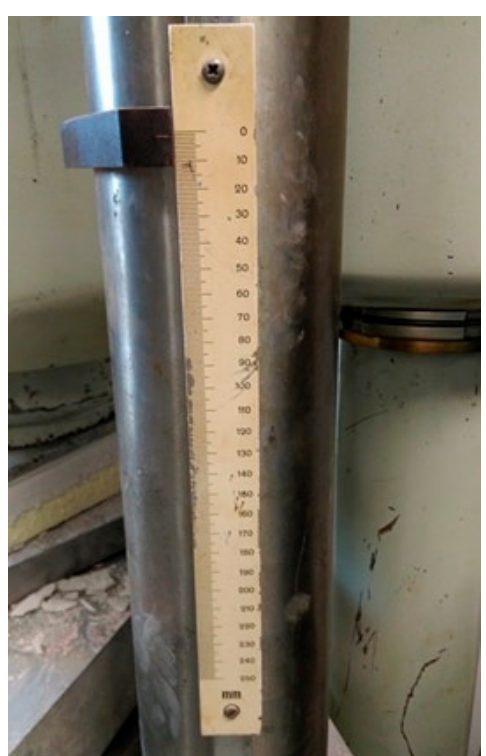

(b)

Figure 3. Polyurethane foam sample during compression in the testing machine (a), straight edge used for measuring deflections of samples (b), universal testing machine with a visible straight edge prior testing (c).

Table 1. Average compressive stress values at $10 \%$ relative strain and average subgrade stiffness reaction for a given thickness along with average subgrade stiffness reaction.

\begin{tabular}{cccc}
\hline $\begin{array}{c}\text { Thickness of the } \\
\text { Sample [cm] }\end{array}$ & $\begin{array}{c}\text { Average Compressive } \\
\text { Stresses at 10\% Relative } \\
\text { Strain for a Given } \\
\text { Thickness [kPa] }\end{array}$ & $\begin{array}{c}\text { Average Subgrade } \\
\text { Stiffness Reaction for a } \\
\text { Given Thickness } \\
\mathbf{K}\left[\mathbf{k N} / \mathbf{m}^{3}\right]\end{array}$ & $\begin{array}{c}\text { Average Subgrade } \\
\text { Stiffness Reaction } \\
\mathbf{K}\left[\mathbf{k N} / \mathbf{m}^{3}\right]\end{array}$ \\
\hline 16 & 300.0 & 18,750 & \\
14.5 & 305.0 & 21034 & \\
14 & 320.0 & 22,857 & 32,073 \\
13.5 & 320.0 & 23,704 \\
13 & 320.5 & 24,654 \\
12.5 & 325.0 & 26,000 \\
12 & 327.5 & 27,292 & \\
9.5 & 336.3 & 32,024 & \\
9 & 338.3 & 35,614 & \\
8 & 340.0 & 37,778 & 41,372 \\
7.5 & 357.7 & 44,719 \\
7 & 357.8 & 41,667 \\
\hline
\end{tabular}


Further calculations in the paper used the average subgrade stiffness of the substrate made of closed-cell polyurethane spray foam in the value of $\mathrm{K}=32,000 \mathrm{kN} / \mathrm{m}^{3}$.

\subsection{Static Calculations for the Plate}

Static calculations for the plate were made with the finite difference method in the variation approach. Apart from the finite element method, the finite difference method is one of the most popular numerical methods used for static calculations of building structures. Many outstanding and fundamental scientific papers on this subject have been created [24-34]. The method has been used in calculations for plate structures [35], tanks [36,37], or surface girders.

This work used the condition for the minimum energy of elastic deformation accumulated while undergoing bending in the plate resting on an elastic substrate described in Functional (2) $[7,21]$.

$$
\begin{gathered}
V=\frac{D}{2} \iint_{A}\left\{\left(\frac{\partial^{2} w}{\partial x^{2}}\right)^{2}+2\left(\frac{\partial^{2} w}{\partial x \partial y}\right)^{2}+\left(\frac{\partial^{2} w}{\partial y^{2}}\right)^{2}+2 v\left[\frac{\partial^{2} w}{\partial x^{2}} \frac{\partial^{2} w}{\partial y^{2}}-\left(\frac{\partial^{2} w}{\partial x \partial y}\right)^{2}\right]\right. \\
\left.+2(1+v) \frac{\alpha t \Delta T}{h}\left(\frac{\partial^{2} w}{\partial x^{2}}+\frac{\partial^{2} w}{\partial y^{2}}+\frac{\partial^{2} \Delta T}{h}\right)\right\} d A \\
+\frac{1}{2} \iint_{A} K w^{2} d A-\iint_{A} q w d A
\end{gathered}
$$

where:

$D=\frac{E h^{3}}{12\left(1-v^{2}\right)}$-plate flexural rigidity,

E-elasticity modulus of material,

v-Poisson's ratio,

$h$-plate thickness,

$w$-plate deflection,

$q$-load perpendicular to the central surface of the plate,

$A$-plate area,

$K$-subgrade stiffness reaction.

Further analysis was based on the adopted denominations:

$$
w_{x x}^{2}=\left(\frac{\partial^{2} w}{\partial x^{2}}\right)^{2} w_{x y}^{2}=\left(\frac{\partial^{2} w}{\partial x \partial y^{2}}\right)^{2} w_{y y}^{2}=\left(\frac{\partial^{2} w}{\partial y^{2}}\right)^{2} w_{x x}=\left(\frac{\partial^{2} w}{\partial x^{2}}\right)^{2} w_{y y}=\left(\frac{\partial^{2} w}{\partial y^{22}}\right)
$$

On the assumption that the Poisson's ratio was $v=0$, and excluding the parameter of temperature, the energy functional changed its form into Formula (3) [11].

$$
V=\frac{D}{2} \iint_{A}\left(w^{2} x x+2 w_{x y}^{2}+w^{2} y y\right)+\frac{1}{2} \iint_{A} K w^{2} d A-\iint_{A} q w d A
$$

The calculations included a reinforced concrete slab with dimensions of $6 \times 6 \mathrm{~m}$ and a thickness of $0.25 \mathrm{~m}$ made of $\mathrm{C} 20 / 25$ concrete with the elasticity modulus $\mathrm{E}=30,000 \mathrm{MPa}$.

The slab was divided by a square discretization grid with a mesh size of $s_{x}=s_{y}=0.25 \mathrm{~m}$. The slab adopted for calculations was characterized by a static diagram, with all edges free (unfixed), loaded in strips circumferentially with the load equal to $q=30 \mathrm{kN} / \mathrm{m}$. The static diagram of the slab after taking into account the symmetry axis along with the assumed division mesh and acting load is shown in Figure 4 [38]. 


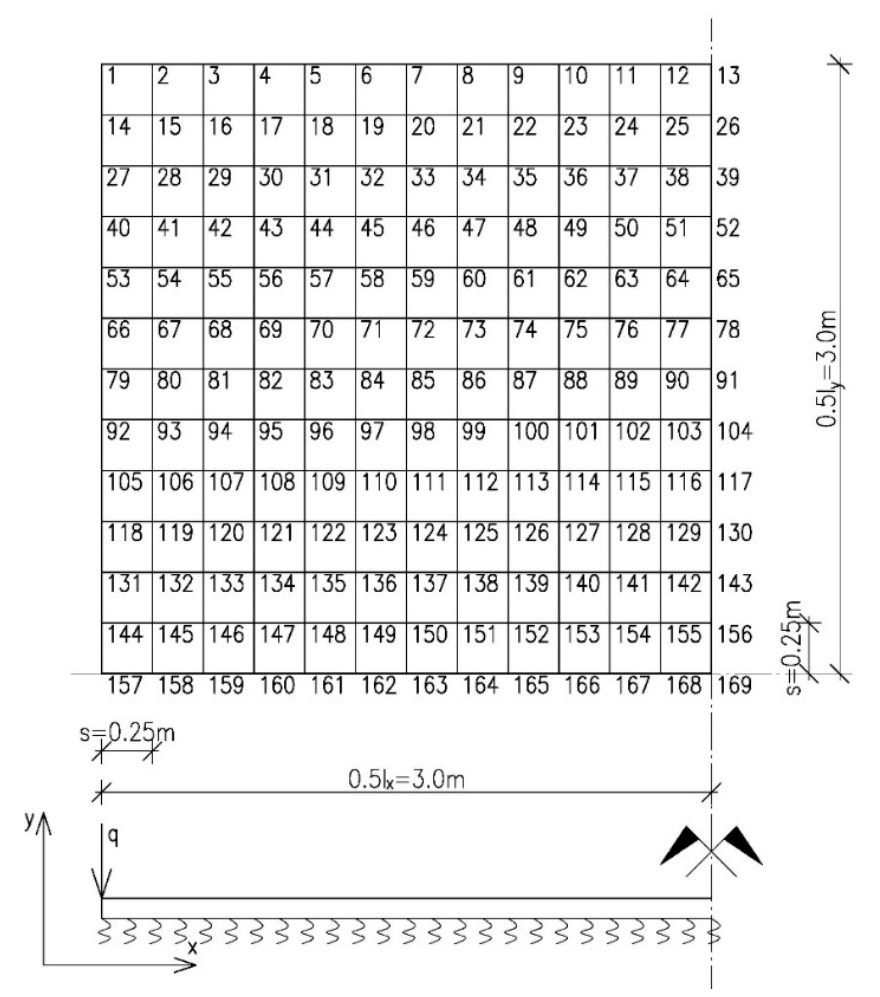

Figure 4. Static diagram with a discretization grid [36].

With the use of Formula (3) for each point of the division mesh, a displacement equation was written. As a result, we obtained a system of equations with 169 unknowns on the assumption that the average substrate subgrade stiffness obtained from laboratory tests [23] was $\mathrm{K}=32,000 \mathrm{kN} / \mathrm{m}^{3}$. To compare the results, the system of equations was calculated once again assuming the subgrade stiffness $\mathrm{K}=50,000 \mathrm{kN} / \mathrm{m}^{3}$, which corresponds to e.g., tightly compacted sand. After calculating the equation systems, we obtained the deflection values at all nodes of the adopted discretization grid.

\section{Results}

Based on Formula (4), we determined the values of the bending moments at all points of the discretization grid [11].

$$
M_{k x}=-\mathrm{D} \frac{w_{k-1}-2 w_{k}+w_{k+1}}{s^{2}}
$$

where:

$M_{k x}$-bending moment at the node $\mathrm{k}$,

$D$-plate flexural rigidity,

$w_{k+1}, w_{k}, w_{k-1}$-deflections at particular nodes of the grid.

Table 2 summarizes the values of bending moments at particular nodes of the plate (Figure 4 ) in the symmetry axis, taking into account the substrate with subgrade stiffness $\mathrm{K}=32,000 \mathrm{kN} / \mathrm{m}^{3}$ and $\mathrm{K}=50,000 \mathrm{kN} / \mathrm{m}^{3}$. The multiplier is the product of the mesh division designated as $\mathrm{s}$ and the load $\mathrm{q}$. 
Table 2. The values of bending moments for two variants of calculation.

\begin{tabular}{|c|c|c|c|}
\hline $\begin{array}{l}\text { Discretisation Grid } \\
\text { Points }\end{array}$ & $\begin{array}{l}\text { The Concrete Slab } \\
\text { Resting on the } \\
\text { Subgrade Stiffness } \\
\mathrm{K}=32,000 \mathrm{kN} / \mathrm{m}^{3}\end{array}$ & $\begin{array}{c}\text { The Concrete Slab } \\
\text { Resting on the } \\
\text { Substrate Subgrade } \\
\text { Stiffness } \\
\mathrm{K}=50,000 \mathrm{kN} / \mathrm{m}^{3}\end{array}$ & Multiplier \\
\hline 157 & 0 & 0 & \multirow{13}{*}{$\mathrm{qs}^{2}$} \\
\hline 158 & -0.833 & -0.811 & \\
\hline 159 & -1.388 & -1.316 & \\
\hline 160 & -1.723 & -1.582 & \\
\hline 161 & -1.889 & -1.732 & \\
\hline 162 & -1.931 & -1.834 & \\
\hline 163 & -1.970 & -1.886 & \\
\hline 164 & -1.996 & -1.913 & \\
\hline 165 & -2.004 & -1.949 & \\
\hline 166 & -2.065 & -1.986 & \\
\hline 167 & -2.118 & -1.998 & \\
\hline 168 & -2.152 & -2.048 & \\
\hline 169 & -2.273 & -2.069 & \\
\hline
\end{tabular}

Table 3 compares the values of deflections and bending moments in the central point of the plate depending on the assumed subgrade stiffness reaction. It also shows the percentage difference in the values of bending moments between the substrate moduli accepted for calculation.

Table 3. The values of deflections and bending moments for two variants of calculation for the central point of the plate.

\begin{tabular}{cccc}
\hline Concrete Slab & Deflections $\left[\mathbf{q s}^{4} / \mathrm{D}\right]$ & $\begin{array}{c}\text { Bending Moments }\left[\mathbf{q s}^{2} \text { ] }\right. \\
\mathbf{M}_{\mathbf{x}}=\mathbf{M}_{\mathbf{y}}\end{array}$ & $\begin{array}{c}\text { Decrease in the Value of } \\
\text { Bending Moment [\%] }\end{array}$ \\
\hline $\begin{array}{l}\text { Resting on the substrate } \\
\text { with subgrade stiffness } \\
\mathrm{K}=32,000 \mathrm{kN} / \mathrm{m}^{3}\end{array}$ & $\mathrm{w}_{169}=35.635$ & $\mathrm{M}_{169}=-2.273$ & - \\
\hline $\begin{array}{l}\text { Resting on the substrate } \\
\text { with subgrade stiffness } \\
\mathrm{K}=50,000 \mathrm{kN} / \mathrm{m}^{3}\end{array}$ & $\mathrm{w}_{169}=23.236$ & $\mathrm{M}_{169}=-1.886$ & 17.03 \\
\hline
\end{tabular}

The above table shows that with an increase in the subgrade stiffness reaction, the values of deflections and bending moments are reduced. The percentage decrease in the value of bending moment for a characteristic central node of the plate 169 for the plate resting on the substrate with subgrade stiffness obtained as a result of laboratory tests equal to $\mathrm{K}=32,000 \mathrm{kN} / \mathrm{m}^{3}$ in comparison to the substrate with a subgrade stiffness $\mathrm{K}=50,000 \mathrm{kN} / \mathrm{m}^{3}$ was $17.03 \%$.

\section{Discussion}

By analyzing the available literature on the subject with the results obtained from the tests and calculations provided in the paper, the obtained results can be divided into two groups: results regarding the properties of the tested insulation material and the results of bending moments for designing floor slabs. Referring to the insulation material, it can be stated that the average value of the subgrade stiffness for spray-applied polyurethane foam is $\mathrm{K}=32,000 \mathrm{kN} / \mathrm{m}^{3}$. In the case of layer plates with a polyurethane foam core in an aluminum cladding laid as a subfloor, the average value of subgrade stiffness is $\mathrm{K}=39,830 \mathrm{kN} / \mathrm{m}^{3}[7,23,38]$. The cited results show partial conformity; however, they clearly indicate that the insulation layer made of spray-applied polyurethane foam is a more deformable substrate, i.e., there will be greater values of deflections and bending moments than in the case of sandwich panels with a polyurethane foam core laid under concrete slabs. 
It was noticed that with an increase in the subgrade stiffness reaction, which did not take into account the influence of underfloor insulation, lower values of deflections and bending moments were obtained. Consequently, this leads to accepting a too small reinforcement area. On the other hand, the slab cooperating with the underlying Winkler substrate receives higher deflections and bending moments, which results in the necessity of applying stronger reinforcement [38]. Damage to floor plates caused by the adoption of incorrect reinforcement or the faulty execution of reinforced concrete structures is a serious problem for the user of the facility. Numerous authors have considered this subject $[4,39,40]$. Although the literature includes papers discussing issues related to the bending of plates on an elastic foundation, they refer to the stratified soil below the floor $[9,13,14]$. This paper shows that it is also important to consider the layer directly under concrete slabs [41,42].

\section{Conclusions}

In heated buildings, the floor is always thermally insulated. The most frequently provided solution are boards made of various insulation materials, as they are easier to lay. Spray insulation is rarely applied due to the installation costs and unpopularity of its application method. Nevertheless, its greatest advantage is the homogeneity of layers free from joints and cracks. The paper demonstrates that the calculation of floors should take into account their layering, which concerns not only the ground and foundation layers, but also the layer of insulation. Excluding the insulation in calculation is a serious engineering mistake, because it leads to a design with insufficient reinforcement, and as a result too low durability and strength of the floor. Negative effects may be damage such as scratches and subsidence, as well as cracks that significantly accelerate the degradation of floor slabs. To emphasize the importance of this structural element, it is worth noting that the cost of proper industrial floor construction in the facility is, depending on its complexity, about $20 \%-25 \%$ of the financial expenditure allocated for its construction. Then, the cost of repairing the floor is high and sometimes exceeds the cost of doing it anew.

"The funders had no role in the design of the study; in the collection, analyses, or interpretation of data; in the writing of the manuscript, or in the decision to publish the results".

Funding: This research received no external funding.

Acknowledgments: The publication was co-financed within the framework of Ministry of Science and Higher Education programme as "Regional Initiative Excellence" in years 2019-2022, Project No. 005/RID/2018/19.

Conflicts of Interest: The author declares no conflict of interest.

\section{References}

1. Kurt, M.; Slavkin, I.; Eriten, M.; McFarland, D.M.; Gendelman, O.L.; Bergman, L.A.; Vakakis, A.F. Effect of 1:3 resonance on the steady-state dynamics of a forced strongly nonlinear oscillator with a linear light attachment. Arch. Appl. Mech. 2014, 84, 1189-1203. [CrossRef]

2. Kurt, M.; Eriten, M.; McFarland, D.M.; Bergman, L.A.; Vakakis, A.F. Strongly nonlinear beats in the dynamics of an elastic system with a strong local stiffness nonlinearity: Analysis and identification. J. Sound Vib. 2014, 333, 2054-2072. [CrossRef]

3. Małasiewicz, A.; Tejchman, J. Industrial Floors; Gdańsk University of Technology Publishing House: Gdańsk, Poland, 2006.

4. Ksit, B.; Szymczak-Graczyk, A. Examples of repair and renovation of industrial floors. Acta Sci. Pol. Archit. 2019, 18, 91-98. [CrossRef]

5. Jasiczak, J. Industrial floors. In Materials, Technologies, Design, Repairs; Addiment Polska Sp. z o.o.: Poznań, Poland, 2001.

6. Hajduk, P. Monolithic concrete floors. Inżynier Budownictwa 2018, 11, 85-88. Available online: http://www.inzynierbudownictwa.pl/technika,materialy_i_technologie,artykul,monolityczne_ podlogi_betonowe_jak_unikac_bledow_cz_i,11298,4 (accessed on 10 October 2019).

7. Deregowska, B.; Szymczak-Graczyk, A. Evaluation of the suitability of polyurethane foam boards treated as underfloor elastic substrate. Mater. Bud. 2017, 537, 126-127. [CrossRef] 
8. Frydrych, K. Studies on Shaping the Value of the Susceptibility Coefficient of the Substrate for Static Calculations of Tunnel Housings. Ph.D. Thesis, AGH, Kraków, Poland, 2012. Available online: https://docplayer.pl/2825799-Badania-nad-ksztaltowaniem-sie-wartosci-wspolczynnika-podatnoscipodloza-dla-celow-obliczen-statycznych-obudowy-tuneli.html (accessed on 10 October 2019).

9. Urbanowski, W. Case studies of bending a round plate connected to a flexible substrate of generalized properties. Zeszyty Naukowe Politechniki Warszawskiej 1956, 3, 33-61.

10. Blakov, В.Z.; Leontev, Н.Н. Beams, Plates and Shells on an Elastic Foundation; Г.И.Ф.М.Л.: Mokkva, Russia, 1960.

11. Kączkowski, Z. Plates. Static Calculations; Arkady: Warszawa, Poland, 2000.

12. Szcześniak, W.; Ataman, M. Vibration of beam resting on the inertial Vlasov-Leontiev foundation under impulse of force. Autobusy 2016, 3, 727-732. Available online: https://www.infona.pl/resource/bwmeta1. element.baztech-f141ed93-eaec-4f11-859d-6597145c47f7 (accessed on 10 October 2019).

13. Wang, Y.H.; Tham, L.G.; Cheung, Y.K. Beams and plates on elastic foundations: A review. Prog. Struct. Eng. Mater. 2005, 7, 174-182. [CrossRef]

14. Ryżyński, W.; Karczewski, B. Determination of calculation parameters of the layered substrate under industrial floors. Nowocz. Hale 2014, 5, 34-38. Available online: https://www.astra-polska.com/wp-content/ uploads/2014/11/5_2014-HAL.pdf (accessed on 10 October 2019).

15. Korhan, O.; Ayse, T.D. Free vibration analysis of thick plates on elastic foundations using modified Vlasov model with higher order finite elements. Int. J. Econ. Manag. 2012, 19, 279-291.

16. Ignaczewski, R. Modern polyurethane insulation systems-Effective protection against heat loss. Izolacje 2017, 1, 44-45.

17. Migda, W.; Szczepański, M.; Jankowski, R. Increasing the seismic resistance of wood-frame buildings by applying PU foam as thermal insulation. Period. Polytech. Civ. Eng. 2019, 63, 480-488. [CrossRef]

18. Suman, B.M.; Srivastava, R.K. Influence of thermal insulation on conductive heat transfer through roof ceiling construction. J. Sci. Ind. Res. 2009, 68, 248-251. Available online: Http://hdl.handle.net/123456789/3145 (accessed on 10 October 2019).

19. Václavík, V.; Valíček, J.; Dvorský, T.; Hryniewicz, T.; Rokosz, K.; Harničárová, M.; Kušnerová, M.; Daxner, J.; Bendová, M. A method of utilization of polyurethane after the end of its life cycle. Annu. Set. Environ. Prot. 2012, 14, 96-106. Available online: http://ros.edu.pl/images/roczniki/archive/pp_2012_005.pdf (accessed on 10 October 2019).

20. Liszkowska, J.; Moraczewski, K.; Borowicz, M.; Paciorek-Sadowska, J.; Czupryński, B.; Isbrandt, M. The effect of accelerated aging conditions on the properties of rigid polyurethane-polyisocyanurate foams modified by cinnamon extract. Appl. Sci. 2019, 9, 2663. [CrossRef]

21. Polish Standard: PN-EN 826: 1998 Determination of Compression Behavior of Thermal Insulation Products; Polish Committee for Standardization: Warsaw, Poland, 1998.

22. Polish Standard: PN-EN 13165:2010 Products for Thermal Insulation in Construction; Rigid Polyurethane Foam Products (PUR) Manufactured in the Factory-Specification; Polish Committee for Standardization: Warsaw, Poland, 2010.

23. Schneider, D.; Szymczak-Graczyk, A. Determination of the polyurethane foam shear modulus In Situ. Mater. Bud. 2019, 557, 62-63. [CrossRef]

24. Gołaś, J. Introduction to the Theory of Plates; Opole University of Technology Publishing House: Opole, Poland, 1972.

25. Donnell, L.H. Beams, Plates and Shells; McGraw-Hill: New York, NY, USA, 1976.

26. Naghdi, P.M. The Theory of Shells and Plates; Handbuch der Physick; Springer: Berlin/Heidelberg, Germany, 1972.

27. Panc, V. Theries of Elastic Plates; Academia: Prague, Czech Republic, 1975.

28. Timoshenko, S.; Woinowsky-Krieger, S. Theory of Plates and Coatings; Arkady: Warszawa, Poland, 1962.

29. Szlilard, R. Theory and analysis of plates. In Classical and Numerical Methods; Cliffs: Englewood, NJ, USA; Prentice-Hall: Upper Saddle River, NJ, USA, 1974.

30. Ugural, A.C. Stresses in Plates and Shells; McGraw-Hill: New York, NY, USA, 1981.

31. Wilde, P. Variational approach of finite differences in the theory of plate. In Proceedings of the Materials of XII Scientific Conference of the Committee of Science PZiTB and the Committee of Civil Engineering of Polish Academy of Sciences, Krynica, Poland, IX 1966. 
32. Kollár, L. Some problems of static analysis of folded plate structures. Period. Polytech. Civ. Eng. 1993, 37, 168-202.

33. Tribiłło, R. Application of the generalized finite difference method for plate calculations. Archiwum Inżynierii Lacdowej 1975, 2, 579-586.

34. Son, M.; Sang Jung, H.; Hee Yoon, H.; Sung, D.; Suck Kim, J. Numerical study on scale Effect of repetitive plate-loading test. Appl. Sci. 2019, 9, 4442. [CrossRef]

35. Szymczak-Graczyk, A. Rectangular plates of a trapezoidal cross-section subjected to thermal load. In IOP Conference Series: Materials Science and Engineering; IOP Publishing: Bristol, UK, 2019; Volume 603, p. 032095. [CrossRef]

36. Buczkowski, W.; Szymczak-Graczyk, A.; Walczak, Z. Experimental validation of numerical static calculations for a monolithic rectangular tank with walls of trapezoidal cross-section. Bull. Pol. Acad. Sci. Tech. Sci. 2017, 65, 799-804. [CrossRef]

37. Szymczak-Graczyk, A. Floating platforms made of monolithic closed rectangular tanks. Bull. Pol. Acad. Sci. Tech. Sci. 2018, 66, 209-219. [CrossRef]

38. Schneider, D. Analysis of the Influence of Thermal Insulation in the Calculations of the Load Floor Capacity. Master's Thesis, Poznan University of Life Sciences, Poznań, Poland, 2018.

39. Szymczak-Graczyk, A.; Ksit, B.; Laks, I. Operational problems in structural nodes of reinforced concrete constructions. In IOP Conference Series: Materials Science and Engineering; IOP Publishing: Bristol, UK, 2019; Volume 603, p. 032096. [CrossRef]

40. Johansson, M. Reinforcement detailing in concrete frame corners. ACI Struct. J. 2001, 98, 105-115.

41. British Standard: BS 8204-2:2002 Screeds, Bases and In Situ Floorings; Concrete Wearing Surfaces. Code of Practice; British Committee for Standardization: London, UK, 2002.

42. Concrete Industrial Ground Floors - A Guide to Their Design and Construction; Technical Raport 34 Fourth Edition; The Concrete Society: Oxford, UK, 2014.

(C) 2020 by the author. Licensee MDPI, Basel, Switzerland. This article is an open access article distributed under the terms and conditions of the Creative Commons Attribution (CC BY) license (http://creativecommons.org/licenses/by/4.0/). 